\title{
BoOKs RECEIVED/ LIVRes RÉÇUS
}

Batt, Sharon. Health Advocacy Inc: How Pharmaceutical Funding Changed the Breast Cancer Movement. Vancouver: UBC Press, 2017. Hardcover (9780774833844)

Bibby, Reginald. Resilient Gods: Being Pro-Religious, Low Religious, or No Religious in Canada. Vancouver: UBC Press, 2017. Paper (9780774890069)

Boucher, Jean-Christophe, and Kim Richard Nossal. The Politics Of War: Canada's Afghanistan Mission 2001-14. Vancouver: UBC Press, 2017. Paper (9780774836289)

Christensen, Johan. The Power of Economists with the State. California: Stanford University Press, 2017. Hardcover (9781503600492)

Clarke, Harold D., Matthew Goodwin, and Paul Whiteley. Brexit: Why Britain Voted To Leave The European Union. Cambridge: Cambridge University Press, 2017. Paper (9781316605042)

Danaher, John and Neil McArthur. Robot Sex: Social and Ethical Implications. Cambridge: The MIT Press, 2017. Hardcover (9780262036689)

De Lagasnerie, Geoffroy. The Art of Revolt: Snowden, Assange, Manning. Stanford: Stanford University Press, 2017. Paper (9781503603325)

Duina, Francesco. Broke and Patriotic: Why Poor Americans Love Their Country. Stanford: Stanford University Press, 2017. Hardcover (9780804799690)

Ferguson, Andrew Guthrie. The Rise of Big Data Policing: Surveillance, Race, and the Future of Law Enforcement. New York: New York University Press, 2017. Hardcover (9781479892822)

Fishman, Jessica M. Death Makes the News: How the Media Censor and Display the Dead. New York: NYU Press, 2017. Paper (9780814760451)

Gans, Herbert J. Sociology And Social Policy: Essays on Community, Economy, and Society. New York: Columbia University Press, 2017. Paper (9780231183055) 
Helleiner, Jane. Borderline Canadianness: Border Crossings and Everyday Nationalism in Nigeria. Toronto: University of Toronto Press, 2016. Hardcover (9781442649057).

Jansen, Robert. Revolutionizing Repertoires: The Rise of Populist Mobilization in Peru. Chicago: University of Chicago Press, 2017. Paper (9780226487441)

Kaye, Julie. Responding To Human Trafficking: Dispossession, Colonial Violence, and Resistance among Indigenous and Racialized Women. Toronto: University of Toronto Press, 2017. Paper (9781487521615)

Keyes, Katherine M., and Sandro Galea. Population Health Science. New York: Oxford University Press, 2016. Paper(9780190459376)

Lempert, Lora Bex. Women Doing Life: Gender, Punishment, and the Struggle for Identity. New York: New York University Press, 2016. Paper (9781479827053)

lvarez, Alex. Unstable Ground: Climate Change, Conflict, and Genocide. Maryland: Rowman \& Littlefield, 2017. Hardcover (9781442265684)

Macias-Rojas, Patrisia. From Deportation to Prison: The Politics of Immigration Enforcement in Post-Civil Rights America. New York: New York University Press, 2016. Paper (9781479831180)

Maghbouleh, Neda. The Limits of Whiteness: Iranian Americans and the Everyday Politics of Race. Stanford: Stanford University Press, 2017. Paper (9781503603370).

McKay, Richard. Patient Zero and the Making of the AIDS Epidemic. Chicago: University of Chicago Press, 2017. Paper (9780226063959).

Miller, J.R. Residential Schools and Reconciliation: Canada Confronts its History. Toronto: University of Toronto Press, 2017. Hardcover (9781487502188)

Minnich, Elizabeth. The evil of banality: On The Life And Death Importance Of Thinking. Maryland: Roman \& Littlefield, 2017. Hardcover (9781442275959)

Mols, Frank, and Jolanda Jetten. The Wealth Paradox: Economic Prosperity And The Hardening Of Attitudes. Cambridge: Cambridge University Press, 2017. Paper (9781107439139) 
Nagra, Baljit. Securitized Citizens: Canadian Muslims'Experiences of Race Relations and Identity Formation Post 9/11. Toronto: University of Toronto Press, 2017. Paper (9781442628663)

Parks, Lisa and Caren Kaplan (Eds.). Life in the Age of Drone Warfare. Durham: Duke University Press, 2017. Paper (9780822369738)

Quinlan, Andrea. The Technoscientific Witness Of Rape: Contentious Histories of Law, Feminism, and Forensic Science. Toronto: University of Toronto Press, 2017. Paper (9781487520601)

Quinlan, Elizabeth, Andrea Quinlan, Curtis Fogel, and Gail Taylor (Eds.). Sexual Violence At Canadian Universities: Activism, Institutional Responses, and Strategies for Change. Waterloo: Wilfred Laurier University Press, 2017. Paper (9781771122832)

Rabinow, Paul. Unconsolable Contemporary: Observing Gerhard Richter. Durham and London: Duke University Press, 2017. Paper (9780822370017)

Ranasinghe, Prashan. Helter-Shelter: Security, Legality, and an Ethic Of Care in an Emergency Shelter. Toronto: University of Toronto Press, 2017. Paper (9781487522063)

Rios, Victor M. Human Targets: Schools, Police, And The Criminalization of Latino Youth. Chicago: The University of Chicago Press, 2017. Paper (9780226090993)

Simon, F.C. Meta-Regulation in Practice: Beyond Normative Views of Morality and Rationality. Oxon: Routledge, 2017. Hardcover (9781138233720).

Seitz, David. A House of Prayer For All People: Contesting Citizenship in a Queer Church. Minnesota: University of Minnesota Press, 2017. Paper (9781517902148).

Tejani, Riaz. Law Mart: Justice, Access, and For-Profit Law Schools. California: Stanford University Press. Paper (9781503603011)

Thomas, Kevin J.A. Contract Workers, Risk, and the War in Iraq: Sierra Leonean Labor Migrants at US Military Bases. Montreal: McGill-Queen's University Press. Paper (9780773551237)

Van den Berg, Axel, Charles Plante, Hicham Raiq, Christine Proulx, and Sam Faustmann. Combating Poverty: Quebec's Pursuit of a Distinctive Welfare State. Toronto: University of Toronto Press, 2017. Hardcover (9781487501563) 
494 C Canadian Journal of Sociology/Cahiers Canadiens de Sociologie 42(4) 2017

Wright II, Earl, and Thomas C. Calhoun (Eds.). What To Expect And How To Respond. Maryland: Rowman \& Littlefield, 2016. Paper (9781475827453)

Young, Cristobal. The Myth of Millionaire Tax Flight: How Place Still Matters for the Rich. Stanford: Stanford University Press, 2018. Paper (9781503603806) 